\title{
School performance in three South East Asian countries: lessons in leadership, decision-making and training
}

\author{
CM Hugues D. Gill \\ Provost's Office, Sunway University, Kuala Lumpur, Malaysia and \\ Department of Education, Oxford University, Oxford, UK, and \\ Elizaveta Berezina \\ Department of Psychology, Sunway University, Kuala Lumpur, Malaysia
}

\begin{abstract}
Purpose - The three neighbouring nations of Indonesia, Malaysia and Singapore participated in the 2009, 2012 and 2015 Programme for International Student Assessment (PISA) cycles. Despite many similarities between the three nations, Singapore has consistently been a top PISA performer, with Malaysia and Indonesia in the bottom third of the international league tables. This paper aims to sketch the comparative Association of South East Asian Nations (ASEAN) context and uses PISA-derived metrics to contrast how differences in decision-making and school leadership, particularly in relation to staff development and training practices, may impact school performance across Indonesia, Malaysia and Singapore.

Design/methodology/approach - Ten scales from the 2015 PISA School Questionnaire for Malaysia, Singapore and Indonesia were analysed using ANOVA and $t$-tests as an aid to exploring the extent to which different approaches to teacher training, school leadership and governance may impact student performance.

Findings - Although Malaysian and Indonesian school principals report higher levels of autonomy than Singaporean peers, other evidence suggests that schools in Singapore may actually have greater decision latitude. Most significantly, Singaporean teachers take responsibility for key staff development decisions and skills transfer, whereas in Indonesia and Malaysia, teacher training is controlled by government administrators, a factor that may be a critical differentiator between the school systems.

Practical implications - In Singapore, teacher training is controlled by and for teachers through professional learning teams within schools and professional learning communities across schools; in Malaysia and Indonesia, similar decisions are taken by external administrators. Giving Malaysian and Indonesian teachers control over their own training could be a simple and powerful reform to target skills gaps and to generalise improvements in pedagogy quickly across schools and thus to lift school performance in these countries.

Originality/value - This paper highlights how differences at systemic and school levels, particularly in approaches to teacher training and leadership and may explain differentials in school performance in three ASEAN education systems.
\end{abstract}

Keywords ASEAN, PISA, Education policy, Evidence-based policymaking, Teacher training, School performance

Paper type Research paper

This research received no specific grant from any funding agency, commercial or not-for-profit sectors. 


\section{Introduction}

Since the mid-1990s, there has been a substantial rise in the number of educational international large-scale assessments (ILSAs; Addey, 2017; Williams and Engel, 2013) and the Programme for International Student Assessment (PISA) launched by the Organisation for Economic Co-operation and Development (OECD) in 2000 has become the most widely used ILSA (Hopfenbeck, 2016). PISA is completed every three years, and uniquely among ILSAs, it aims to measure "young people's ability to use their knowledge and skills to meet real-life challenges. [...] [and] the student, family and institutional factors that can help to explain differences in performance" (OECD, 2006, pp. 16-17). Despite many critiques of PISA (Fernandez-Cano, 2016; Klette et al., 2016; Thompson and Allen, 2012) and its suitability for making valid cross-national comparisons (E1 Masri et al., 2016; Gorur et al., 2019; Jerrim et al., 2018), PISA results have become catalysts for change in education policy debates (Baird et al., 2016; Hopfenbeck et al., 2018) and have been used to as the basis for national reforms (OECD, 2019; Schleicher, 2009).

\section{Programme for International Student Assessment in South East Asia}

In all, six members of the Association of South East Asian Nations (ASEAN) have participated in PISA: Indonesia and Thailand from 2000, Malaysia and Singapore from 2009, Viet Nam from 2015, Brunei Darussalam and the Phillipines in 2018. Singapore and Vietnam have performed very well in PISA, but Malaysia, Indonesia and Thailand have been consistently placed in the bottom third of participating countries (Thien, 2016) (Table 1).

The comparatively weak performance of Malaysian students came as something of a shock to Malaysian policymakers, and it provoked concerns that Malaysia might not be able to achieve developed status because young Malaysians would not have the skillset required for the economy to break out of the so-called middle income trap (Jimenez et al., 2013). The Malaysian government responded to the challenge by commissioning UNESCO to undertake the Malaysia Education Policy Review, which led to a series of recommendations incorporated in the Malaysia Education Development Plan 2013-2025 (Azmy et al., 2016). This plan has the explicit objective of raising Malaysian students' PISA scores from the bottom third to the top global third much closer to Singapore (Abdullah and Peters, 2015). Reforms to the Malaysian curriculum included the introduction of areas that were thought to be central to Singapore's comparative success such as the development of soft skills, ethical decision-making, problem solving, team work and higher-order thinking skills (HOTS) (Aisyah et al., 2019; Hudin et al., 2018). The fact that the PISA 2015 results for Malaysia were better than those for 2012 was widely seen as supporting the initial curricula reforms programme (Abas and Mohd Shahar, 2016), although the OECD did not publish the data with the main PISA results because of problems with school sampling. However, it has been argued that Malaysia must reform more than the curriculum to improve the nation's PISA performance (Perera and Asadullah, 2019; The World Bank, 2011).

Table 1.

2015 PISA scores for the five participating ASEAN nations

\begin{tabular}{lccc}
\hline & Maths & Reading & Science \\
\hline Indonesia & 386 & 403 & 403 \\
Malaysia & 446 & 443 & 443 \\
Singapore & 564 & 556 & 556 \\
Thailand & 415 & 421 & 421 \\
Viet Nam & 495 & 525 & 525 \\
\hline
\end{tabular}




\section{The global education reform model}

Various multi-lateral educational organisations such as the IEA, UNESCO, World Bank and OECD promote a package of reforms in school leadership, governance and autonomy (Grimmett, 2018; Klees, 2008; Sahlberg, 2016; Shahjahan, 2016; Verger et al., 2018b), which have been termed the global education reform model (GERM; Sahlberg, 2006). Among other prescriptions GERM proposes that school leaders and teachers should have high levels of autonomy, schools should be responsible for staff training and development and that schools should be accountable to parents (Sahlberg, 2016); PISA data have been used to justify such reforms in various Asian jurisdictions, including Hong Kong (Adamson et al., 2017), Japan (Kimura and Tatsuno, 2017; Tasaki, 2017), Shanghai (Ngok, 2007; Sellar and Lingard, 2013; Tan, 2012, 2017) and Singapore (Lee et al., 2014; Tan, 2011).

\section{Global education reform model in Singapore, Malaysia, and Indonesia}

The government of Singapore was a very early adopter of GERM, and all state and statesupported schools are directly accountable to parents and alumni through governing bodies established under the School Boards (Incorporation) Act 1990. Although levels of autonomy are graduated across state and quasi-independent state-funded schools, most finance, staffing and training decisions are taken at the school level (Chan and Tan, 2008). Even where schools do not have discretion, centralised government control has largely been replaced by the formation of school collectives or clusters with areas like administration and staff development shared across schools (Gopinathan and Lee, 2018).

Malaysia legally established parent-teacher associations (PIBG) in 1973, and Malaysian parents "have the right to be fully informed about the school's mission, current performance, and annual improvement programme” (MoE, 2013, p. E-24). However, PIBGs are only consultative bodies, and most school decision-making ultimately rests with civil servants because the Malaysian approach to decentralisation means "more decision rights being awarded to state and district offices. Officials will have more say in identifying areas of improvement for their states, districts, and schools, and in tailoring solutions" (MoE, 2013, p. E-24). Malaysia to some extent copied the Singaporean model by introducing school clusters in 2006, but as the Malaysia Education Blueprint 2013-2025 (MoE, 2013) makes clear, schools remain accountable to district officials rather than to governing bodies with parent and alumni representation. This means that in practice, the majority of decisions in areas like finance, staffing and teacher training are taken by external administrators, rather than within Malaysian schools.

Indonesia also appeared to be an early adopter of GERM when in 1990, the government devolved to school principals' responsibility for some aspects of finance, administration and staff training under the provisions of Peraturan Permerintah Republik Indonesia, No. 28/ 1990, Tentang Pendidikan Dasar. This was followed in 2001 by the establishment of school governing bodies, but in practice, only about $25 \%$ of the governors are parents or alumni, and the majority membership is teachers and government officials so the emphasis is on "partnership" rather than school-level decision-making about staffing and training matters (Bandur, 2012). Moreover, despite apparent school-level autonomy, parents take very little active part in school governance, and district- and provincial-level officials are prone to interfere even in relatively small decisions (Vernez et al., 2012; Hutabarat, 2015).

Thus, within ASEAN, there appear to be two very distinct approaches to the ways in which decisions are made about school staffing and training. PISA 2015 data provide a means to empirically compare the extent to which higher performing Singapore schools may differ from lower-performing Malaysian and Indonesian schools and how these differences 
may play out in terms of leadership, decision-making and staff development and therefore help to identify areas in which reforms may be targeted to improve school performance.

\section{School measures in the programme for international student assessment}

As part of PISA 2015 cycle, the school questionnaire contained items that were designed to assess aspects of school leadership, autonomy, staff training and related contextual features salient to GERM (OECD, 2016). Using primary items from the PISA 2015 School Questionnaire, the OECD aggregated the scores for individual items about school leadership, autonomy, staff training and other related issues into bigger composite scales designed to capture broad areas of school activity; the calculations used the generalised partial credit model (GPCM) and weighted likelihood estimates to develop an internationally comparable metric with a mean of zero and standard deviation of one that provides a standardised score for each school (OECD, 2015). A selection of these PISA composite scales and the areas of activity assessed are shown in Table 2 below.

Research has shown that the dimensions shown in Table 2 are critical in achieving school performance (Burns et al., 2016), so it is clearly of interest to establish how the three immediate neighbours Indonesia, Malaysia and Singapore may differ. Thus, the present research examined the score differentials on these composite scales for midperforming Malaysia relative to Singapore and Indonesia, to highlight areas of similarity or difference and to explore the extent to which these factors might impact school performance.

\section{Methodology}

The 2015 PISA School Questionnaire data for Malaysia, Singapore and Indonesia were downloaded from the OECD PISA website, and the scores for the composite scales from the PISA School Questionnaire shown in Table 2 above were extracted for the schools sampled in the three nations. As the standardisation process used to calculate the composite scale scores inevitably yields a distribution of scores with a notional mean of zero, it follows that half the scores are negative, making it difficult to compare the magnitude of scores easily between nations. Therefore, to make it easier to interpret the similarities and differences in scores, each of the scales was transformed by adding the minimum score in the range for each scale to all the scores in that scale so that all the aggregate scales were then expressed as positive numbers (for the composite scale characteristics, see OECD, 2015, pp. 325-327). This meant that was immediately possible to see how one country had scored relative to another and also to see any trends across different areas of activity. As the scale scores for

Table 2.

The PISA 2015 School Questionnaire derived variables

\section{Scale}

LEAD

LEADCOM

LEADINST

LEADPD

LEADTCH

RESPCUR

RESPRES

SCHAUT

TEACHBEHA

STRATIO
Area assessed

Leadership by the principal

Teaching activities aligned with curriculum Instructional leadership within the school

School-level decisions about professional development Teachers participation in leadership decision-making

School-level responsibility for curriculum

School-level decisions about resource allocation

School autonomy overall

Teacher behaviour and/or resistance hindering learning Student-teacher ratio 
some schools were not available, the minimum and maximum number of schools included in the survey and the means of the transformed scale scores for the ASEAN nations are shown in Table 3 below.

\section{Lessons in leadership, decision-making and training}

\section{Analysis and results}

As the composite scale scores were normally distributed, it was possible to use parametric procedures to make contrasts between the scores for schools across the three nations using a one-way analysis of variance (ANOVA). As is immediately apparent from Table 4, in almost every case, there were significant differences between the scores for schools in the three nations, so to explore these differences further, a series of individual $t$-tests was conducted. Despite the fact that the ANOVA had shown most of the composite scale means to be different across the three nations, for the sake of parsimony and to minimise the likelihood of Type I errors, the Bonferroni correction was applied to the probabilities such that only those probabilities less than $0.005(0.05 / 10)$ would be considered significant. To make interpretation of the findings easier, the first named nation in each column was entered into each analysis first. This means that a positive $t$ indicates that the mean score for the first nation named in each column was higher than the score for the second named nation; it naturally also follows that a negative $t$ shows that the mean score for the first named nation in each column was lower than for the second nation. The results are summarised in Table 5 .

\begin{tabular}{|c|c|c|c|c|}
\hline PISA Scale & $\begin{array}{c}\text { Indonesia } \\
(n=217-236)\end{array}$ & $\begin{array}{c}\text { Malaysia } \\
(n=219-225)\end{array}$ & $\begin{array}{c}\text { Singapore } \\
(n=171-176)\end{array}$ & Toble 2 \\
\hline LEAD & 6.92 & 7.43 & 6.98 & Transformed mean \\
\hline LEADCOM & 5.03 & 5.60 & 5.18 & scores for the PISA \\
\hline LEADINST & 4.02 & 4.60 & 4.26 & 2015 School \\
\hline LEADPD & 4.00 & 4.06 & 4.00 & Questionnaire \\
\hline LEADTCH & 4.14 & 4.30 & 3.83 & Questionmaire \\
\hline RESPCUR & 1.76 & 0.37 & 1.07 & derived variables for \\
\hline RESPRES & 1.30 & 0.35 & 0.50 & the schools sampled \\
\hline TEACHBEHAV & 1.25 & 1.83 & 2.16 & in the three \\
\hline SCHAUT & 0.83 & 0.38 & 0.74 & comparator ASEAN \\
\hline STRATIO & 15.18 & 11.66 & 11.88 & nations \\
\hline
\end{tabular}

\begin{tabular}{|c|c|c|c|}
\hline PISA scale & $\mathrm{F}$ & Probability value & Table 4. \\
\hline LEAD & 13.79 & 0.001 & results for the \\
\hline LEADCOM & 21.99 & 0.001 & comparison of the \\
\hline LEADINST & 22.30 & 0.001 & transformed scores \\
\hline LEADPD & 1.53 & 0.217 & for the PISA 2015 \\
\hline LEADTCH & 9.07 & 0.001 & \\
\hline RESPCUR & 146.28 & 0.001 & School Questionnaire \\
\hline RESPRES & 62.05 & 0.001 & derived variables for \\
\hline SCHAUT & 306.35 & 0.001 & schools in Malaysia, \\
\hline TEACHBEHA & 55.02 & 0.001 & Indonesia and \\
\hline STRATIO & 17.25 & 0.001 & Singapore \\
\hline
\end{tabular}


School leadership and decision-making

Given the supposed centrality of leadership to PISA success, the findings for the main leadership indices shown in Table 5 are perhaps surprising. Malaysia scores significantly higher than both Indonesia and Singapore for the leadership given by principals (LEAD), alignment of teaching and curriculum (LEADCOM) and instructional leadership within schools (LEADINST). However, there are no significant differences between the three nations for school-level decision-making about professional development (LEADPD), but Malaysia and Indonesia have similar scores for teacher participation in decision-making (LEADTCH), and these scores are significantly higher than those for Singapore. This suggests that Malaysian principals are providing more leadership than their peers in Singapore or Indonesia, but that this is not associated with a greater focus on professional development. Indeed, although Malaysian and Indonesian schools have higher levels of teacher participation in decision-making than the higher performing Singapore schools, this is not associated with any significant differences in the amounts of professional development provided for staff.

\section{Responsibility for curriculum and resources}

The indices of school-level responsibility for curriculum (RESPCUR) and resource allocation (RESPRES) appear to show that principals and teachers in Malaysia have significantly less control over the curriculum than those in Indonesia and Singapore. Malaysian schools have the same amount of control of resources as their Singaporean peers, but both have less control than Indonesian principals. This suggests Malaysian principals have least autonomy over what is taught, and in common with their Singaporean colleagues, may have only moderate control over resources.

\section{School autonomy}

The composite measure of school autonomy (SCHAUT) suggests that Malaysian and Singaporean principals have similar levels of overall autonomy, but that both have rather less independence than their peers in Indonesia.

\section{Teacher behaviour}

It appears that teacher behaviours and resistance which hinder learning (TEACHBEHA) are more prevalent in Malaysia than Indonesia, but perhaps surprisingly that they are most prevalent in Singapore.

Table 5.

Summary $t$-test results comparing the mean transformed scores for the PISA 2015

School Questionnaire derived variables for schools in Malaysia, Indonesia and Singapore

\begin{tabular}{lccc}
\hline PISA scale & Malaysia vs Indonesia & Malaysia vs Singapore & Singapore vs Indonesia \\
\hline LEAD & $4.66^{*}$ & $4.20^{*}$ & 0.53 \\
LEADCOM & $6.30^{*}$ & $4.88^{*}$ & 1.62 \\
LEADINST & $6.35^{*}$ & $3.92^{*}$ & 2.70 \\
LEADTCH & 1.43 & $4.49^{*}$ & $-3.00^{*}$ \\
RESPCUR & $-17.35^{*}$ & $-8.79^{*}$ & $-7.31^{*}$ \\
RESPRES & $-9.9^{*}$ & -2.03 & $-7.73^{*}$ \\
SCHAUT & $-22.05^{*}$ & 0.92 & $-5.16^{*}$ \\
TEACHBEHA & $6.70^{*}$ & $-17.82^{*}$ & $11.00^{*}$ \\
STRATIO & $-4.59^{*}$ & -0.76 & $-4.34^{*}$ \\
Note: ${ }^{*} p<0.005$ & & &
\end{tabular}




\section{Student-teacher ratio}

Indonesia has a significantly higher student-teacher ratio (STRATIO) of approximately 15:1 in comparison to Malaysia and Singapore, which both have a ratio of approximately 12:1, but the fact that there is no significant difference in the student-teacher ratio between Malaysia and Singapore suggests that any differences between Malaysia and Singapore are not simply due to staffing numbers.

\section{Discussion}

The findings reported above make it clear that there are some significant differences between Malaysian schools, their higher performing Singaporean counterparts and the lower performing Indonesian schools. This suggests that the differences in policy and governance may translate into significant differences in school leadership and the ways in which schools approach decision-making in key areas around staffing and development, though not necessarily in the ways that might be seen as consistent with GERM.

\section{Student-teacher ratios}

The fact that student-staff ratios are higher in Indonesia than Malaysia suggests that any school performance differences could be related to the challenges of teaching bigger classes. However, the fact that there are no significant differences between Malaysia and Singapore suggests that any differences in school performance across these two nations do not arise from differences in relative resourcing levels between the two nations, rather that the performance differentials may be related to differences in areas such as leadership, staffing and professional development (Hanushek and Woessmann, 2017).

\section{School autonomy, leadership and teacher behaviours}

Malaysian principals report similar levels of overall autonomy to those of higher-performing Singapore, but both Malaysia and Singapore principals report having rather less autonomy than Indonesian peers. Although Malaysian and Indonesian teachers appear to have higher levels of participation in school decision-making than their Singaporean peers, this is not associated with greater professional development opportunities. Lastly, Singaporean principals report higher levels of teacher behaviours and resistance that hinder student learning in comparison to Malaysian teachers, with Malaysian teachers being seen as hindering learning more than their Indonesian peers. Taken together, these factors suggest that Malaysian and Indonesian schools should perform better than Singaporean schools (Ingersoll et al., 2018), yet precisely the opposite is the case. Indeed, in this context, the ways in which these factors combine differently at school level may help to explain the performance differences across the three nations.

Although autonomy is usually considered beneficial to school performance, it may only benefit schools that have a strong academic ethos and that are already performing well within clear and supportive governance structures (You and Morris, 2016). Autonomy in the absence of sound governance and administrative competence may lead to weaker performance (Hanushek et al., 2011). As we have seen, in practice, Singapore schools have considerable autonomy and are governed by independent governing bodies and clusters that also hold principals accountable (Chan and Tan, 2008). In Malaysia, PIBGs and school clusters appear to have little authority, and schools have little real autonomy because most decision-making and accountability actually rest with civil servants (MoE, 2013, p. E-24), and this may explain why apparently high levels of participation in decision-making have no apparent impact in other areas. In Indonesia, the preponderance of government officials and teachers on governing bodies means that the discretion of principals is very limited, 
decision-making is consensual and there is little accountability (Bandur, 2012). These factors may be further compounded by high levels of teacher participation in decision-making because this may actually make it more difficult for principals to drive improvements in school performance by, for example challenging existing skills levels and implementing professional development programmes to address deficits. In Malaysia and Indonesia, principals are constrained by collectivist management expectations (Koo and Park, 2018), and this means principals are mostly focused on maintaining traditional hierarchies and group harmony rather than dealing with more difficult issues such as teacher performance (Bush et al., 2018). By contrast, Singaporean principals are noted for displaying high levels of assertiveness and competitiveness, even though such characteristics are not congruent with Asian behavioural expectations, and it is these factors that drive school improvement (Walker and Hallinger, 2015). This may also explain why Singaporean teachers are considered to hinder student learning more than Malaysian teachers, who in turn hinder student learning more than their Indonesian peers. In this context, "hindrance" may mostly reflect "resistance" to principals who are attempting to drive improvement. In Singapore, schools most staffing and development decisions are taken at the school level (Chan and Tan, 2008), and this means that principals can make decisions that are likely to encounter resistance. In Malaysia, decisions about most staffing issues are controlled by local government (MoE, 2013), so perhaps the reason principals encounter less resistance is that they are not actually able to take any decisions that might provoke resistance from teachers. In Indonesia, principals are even more constrained because the appointment and terms of full-time teachers are wholly controlled by central government, no teachers are ever fired and there are no external motivators for improvement (Lewis and Pattinasarany, 2009). Thus, it seems reasonable to conclude that as decision-making, particularly about matters directly relating to staff, moves further away from schools and from principals, the harder it is to drive changes or improvements that may impact school performance.

\section{Staff training and development}

Given the above, it may initially seem paradoxical that principals in Malaysia, Indonesia and Singapore report school-level decision making about staff development and training at roughly equal levels. It is well appreciated that teacher training is perhaps the most significant way to improve school performance in schools throughout ASEAN (Hallinger and Walker, 2017), particularly if such training includes giving school principals the skillset needed to improve teacher performance (Lee and Nie, 2017). Thus, it might be expected that higher-performing Singapore might report greater levels of decision-making by principals about teacher training. However, the apparent similarity may mask a much more significant disparity because, for any training and development exercise to be effective, it must obviously be relevant, which means it is important who actually makes decisions about development exercises, and principals may not always be those best placed.

Despite the fact that the Malaysia Education Blueprint 2013-2025 highlights the importance of effective professional development for all teachers, the reality remains that decisions are not made at school level because "The Ministry will [. . . identify which areas teachers need support in, and will then provide as much targeted support as possible." (MoE, 2013, pp. 5-10). The Malaysian government has introduced a National Professional Qualification for Educational Leaders, which is mandatory for those who aspire to become principals (Ng, 2017), but it has been suggested that the type of school leadership being taught is along traditional lines (Bush and Ng, 2019), so it is unlikely to impact school performance. In Indonesia, there has been very little school-level decision-making about training and development because the focus of activity has been on a nationwide 
programme to get all teachers to the levels of professional competence necessary for government certification (Fahmi et al., 2011), though to date, progress has been at best mixed (Harjanto et al., 2018). Furthermore, the fact that district and provincial officials interfere in decision-making about training means that the types of training and development provided may not be those that are actually required by schools, irrespective of government certification requirements (Vernez et al., 2012; Hutabarat, 2015). Thus, despite the fact that decision-making about teacher training in Malaysian and Indonesian schools may appear to be similar to Singapore, the focus of those decisions and the actual decisionmakers may be quite different.

In Singapore, schools' staff training and development is not controlled by principals or administrators, but by teachers themselves. Training is commissioned and delivered through professional learning communities (PLCs) within each school, each consisting of professional learning teams (PLTs) normally organised on the basis of subject discipline, which are tasked to share best practice amongst colleagues in a structured fashion (Hairon and Tan, 2017). As Hairon and Tan acknowledge, this is in part only possible because Singapore is small enough for the central authorities to ensure that PLCs and PLTs are functioning correctly, but they also note that Shanghai, with a population of over 20 million, has been able to evolve a very similar system. Other scholars have already identified that the PLC model has the capacity to turn around poor-performing schools in Malaysia and Indonesia (Harris and Jones, 2017), and it has been suggested that PLCs should be adopted across Malaysia (Hassan et al., 2018). Indeed, given that teachers in low-performing ASEAN schools are generally receptive to training and development exercises (Ansawi and Pang, 2017), it seems logical that empowering Malaysian and Indonesian schools to decide and disseminate training via PLCs might be a very effective way to lift overall performance.

\section{Implications for Malaysian and Indonesian schools}

The findings presented here are based upon the results of a survey, and this means that they are subject to all the caveats and limitations that are associated with any self-report measure. Nevertheless, there do appear to be some significant differences between the highperforming schools of Singapore and those of Malaysia and Indonesia. School autonomy, leadership and accountability all have some part to play in achieving high levels of school performance, but irrespective of systemic factors, levels of training and the ways in which teachers take part in professional development may be most important and easiest to address (Hanushek and Woessmann, 2017). The right type of training improves principal effectiveness across ASEAN (Hallinger and Walker, 2017), which in turn improves teacher performance (Lee and Nie, 2017). When teachers then take control of their own professional development, the impact may be increased (Hairon and Tan, 2017). If, as seems likely, the Malaysian reforms begun in 2013 have begun to yield some positive improvements, then the quickest way to multiply them may be through better trained principals and teachers empowered to take control of their own development. Although Indonesia is starting from a lower base, this recipe may be equally applicable to Indonesia (Harjanto et al., 2018). Further reforms around school governance and accountability in line with the measures that have proved effective in Singapore would certainly be desirable, but they would also be slower and more complex to implement, so may not be so pressing as reforming control and access to training and development.

\section{Conclusions}

In many respects, Malaysian schools are closer to those in Singapore than Indonesia, but school performance on PISA is lower than this would imply. Despite recent 
reforms, in practice, Malaysian and Indonesian schools appear to have lower levels of autonomy, accountability to parents and real decision-making latitude than Singaporean schools. In particular, there is a marked difference in the approach to staff training and development. In Malaysia and Indonesia, decisions about key staffing, training and development matters appear to be reserved to government administrators, but in Singapore, training is controlled by and for teachers. Introducing PLTs within schools and PLCs across schools could be the most efficient way to target skills gaps and to generalise improvements in pedagogy quickly in school clusters and possibly even across ASEAN nations. Thus, it is not the apparent level of decision-making that is important, but the level at which important decisions are made. Empowering teachers to make more decisions about their own training and professional development could be a relatively simple and easy reform that would help to lift school performance in all the countries of South East Asia.

\section{References}

Abas, A. and Mohd Shahar, F. (2016), "PISA 2015: Malaysia shows significant improvement in math, science and reading”, New Straits Times, 6 December, available at: www.nst.com.my/news/2016/12/194973/ pisa-2015-malaysia-shows-significant-improvement-math-science-reading

Abdullah, A. and Peters, R. (2015), "Malaysia's Post-PISA2012 direction", International Journal of Culture and History (Ejournal)), Vol. 1 No. 1, pp. 15-20, doi: 10.18178/ijch.2015.1.1.003.

Adamson, B., Forestier, K., Morris, P. and Han, C. (2017), "PISA, policymaking and political pantomime: education policy referencing between England and Hong Kong", Comparative Education, Vol. 53 No. 2, pp. 192-208, doi: 10.1080/03050068.2017.1294666.

Addey, C. (2017), “The assessment culture of international organizations: from philosophical doubt to statistical certainty through the appearance and growth of international education assessments", in Alarcón, C. and Lawn, M. (Eds), Pupil Assessment Cultures in Historical Perspective, Peter Lang, Frankfurt am Main, pp. 1-23.

Ansawi, B. and Pang, V. (2017), "The relationship between professional learning community and lesson study: a case study in low performing schools in Sabah, Malaysia”, Sains Humanika, Vol. 9 Nos 1/3, pp. 63-70.

Baird, J.A., Johnson, S., Hopfenbeck, T.N., Isaacs, T., Sprague, T., Stobart, G. and Yu, G. (2016), "On the supranational spell of PISA in policy”, Educational Research, Vol. 58 No. 2, pp. 121-138, doi: 10.1080/00131881.2016.1165410.

Bandur, A. (2012), "School-based management developments and partnership: evidence from Indonesia", International Journal of Educational Development, Vol. 32 No. 2, pp. 316-328, doi: 10.1016/j.ijedudev.2011.05.007.

Burns, T., Köster, F. and Fuster, M. (2016), Education Governance in Action: Lessons from Case Studies, OECD Publishing, Washington, DC and Paris, doi: 10.1787/9789264262829-en.

Bush, T., Hamid, S.A., Ng, A. and Kaparou, M. (2018), "School leadership theories and the Malaysia education blueprint: findings from a systematic literature review", International Journal of Educational Management, Vol. 32 No. 7, pp. 1245-1265, doi: 10.1108/IJEM-06-2017-0158.

Bush, T. and Ng, A.Y.M. (2019), "Distributed leadership and the Malaysia education blueprint: from prescription to partial school-based enactment in a highly centralised context", Journal of Educational Administration, Vol. 57 No. 3, pp. 279-295, doi: 10.1108/JEA-11-2018-0206.

Chan, D. and Tan, J. (2008), "Privatization and the rise of direct subsidy scheme schools and independent schools in Hong Kong and Singapore", International Journal of Educational Management, Vol. 22 No. 6, pp. 464-487, doi: 10.1108/09513540810895417. 
El Masri, Y.H., Baird, J.A. and Graesser, A. (2016), "Language effects in international testing: the case of PISA 2006 science items", Assessment in Education: Principles, Policy and Practice. Routledge, Vol. 23 No. 4, pp. 427-455, doi: 10.1080/0969594X.2016.1218323.

Fahmi, M., Maulana, A. and Yusuf, A.A. (2011), "Teacher certification in Indonesia: a confusion of means and ends", Center for Economics and Development Studies (CEDS), Vol. 3 No. 1, pp. 1-18.

Fernandez-Cano, A. (2016), "A methodological critique of the PISA evaluations", RELIEVE, Vol. 22 No. 1, pp. 1-16, doi: 10.7203/relieve.22.1.880.

Gopinathan, S. and Lee, M.H. (2018), "Excellence and equity in high-performing education systems: policy lessons from Singapore and Hong Kong/excelencia y equidad en sistemas educativos de alto rendimiento: lecciones de las políticas educativas en Singapur y Hong Kong”, Infancia y Aprendizaje, Vol. 41 No. 2, pp. 203-247, doi: 10.1080/ 02103702.2018.1434043.

Gorur, R., Sørensen, E. and Maddox, B. (2019), "Standardizing the context and contextualizing the standard: translating PISA into PISA-D”, in Prutsch, M. (Ed.), Science, Numbers and Politics, Palgrave Macmillan, Cham, doi: 10.1007/978-3-030-11208-0_14.

Grimmett, P.P. (2018), “Canada's Trojan horse: labor mobility legislation: concealing deregulation and an attack on teacher professionalism and the common good", in Hobbel, N. and Bales, B.L. (Eds), Navigating the Common Good in Teacher Education Policy: Critical and International Perspectives, Routledge, Abingdon, pp. 213-224.

Hairon, S. and Tan, C. (2017), "Professional learning communities in Singapore and Shanghai: implications for teacher collaboration", Compare: A Journal of Comparative and International Education, Vol. 47 No. 1, pp. 91-104, doi: 10.1080/03057925.2016.1153408.

Hallinger, P. and Walker, A. (2017), "Leading learning in Asia - emerging empirical insights from five societies", Journal of Educational Administration, Vol. 55 No. 2, pp. 130-146.

Hanushek, E.A. and Woessmann, L. (2017), "School resources and student achievement: a review of cross-country economic research", Cognitive Abilities and Educational Outcomes, Springer, Champagne, pp. 149-171.

Hanushek, E.A., Link, S. and Woessmann, L. (2011), "Does school autonomy make sense everywhere? Panel estimates from PISA", NBER Working Paper, Cambridge, MA, doi: 10.1017/ CBO9781107415324.004.

Harjanto, I., Lie, A., Wihardini, D., Pryor, L. and Wilson, M. (2018), "Community-based teacher professional development in remote areas in Indonesia", Journal of Education for Teaching, Vol. 44 No. 2, pp. 212-231.

Harris, A. and Jones, M. (2017), "Leading school turnaround and improvement in Malaysia and Indonesia”, Working Papers Series No. 2/2017, The Head Foundation, Singapore, February 2018, doi: 10.13140/RG.2.2.11337.24168.

Hopfenbeck, T.N. (2016), "The power of PISA - limitations and possibilities for educational research", Assessment in Education: Principles, Policy and Practice. Routledge, Vol. 23 No. 4, pp. 423-426, doi: 10.1080/0969594X.2016.1247518.

Hopfenbeck, T.N., Lenkeit, J., El Masri, Y., Cantrell, K., Ryan, J. and Baird, J.A. (2018), “Lessons learned from PISA: a systematic review of peer-reviewed articles on the programme for international student assessment", Scandinavian Journal of Educational Research, Vol. 62 No. 3, pp. 333-353, doi: 10.1080/00313831.2016.1258726.

Hutabarat, W. (2015), "Implementation of school based management in Indonesia (affecting work motivation, job-satisfaction, and teacher job-performance)", International Journal of Sciences: Basic and Applied Research, Vol. 22 No. 2, pp. 428-440.

Jerrim, J., Parker, P., Choi, A., Chmielewski, A.K., Sälzer, C. and Shure, N. (2018), "How robust are crosscountry comparisons of PISA scores to the scaling model used?", Educational Measurement: Issues and Practice, Vol. 37 No. 4, pp. 28-39. 
Jimenez, E., Nguyen, V.T. and Patrinos, H.A. (2013), "Human capital development and economic growth in Malaysia and Thailand: stuck in the Middle?", Human Capital Formation and Economic Growth in Asia and the Pacific, Routledge, pp. 141-162, doi: 10.4324/9780203778739.

Klees, S.J. (2008), "A quarter century of neoliberal thinking in education: misleading analyses and failed policies”, Globalisation, Societies and Education, Vol. 6 No. 4, pp. 311-348.

Koo, H. and Park, C. (2018), "Foundation of leadership in Asia: leader characteristics and leadership styles review and research agenda", Asia Pacific Journal of Management, Vol. 35 No. 3, pp. 697-718, doi: 10.1007/s10490-017-9548-6.

Lee, A.N. and Nie, Y. (2017), "Teachers' perceptions of school leaders' empowering behaviours and psychological empowerment: evidence from a Singapore sample", Educational Management Administration and Leadership, Vol. 45 No. 2, pp. 260-283, doi: 10.1177/1741143215578448.

Lewis, B. and Pattinasarany, D. (2009), "Determining citizen satisfaction with local public education in Indonesia: the significance of actual service quality and governance conditions", Growth and Change, Vol. 40 No. 1, pp. 85-115.

MoE (2013), Malaysia Education Blueprint 2013-2025, Policy Document, MoE, Putrajaya, doi: 10.1016/ j.tate.2010.08.007.

Ng, A.Y.M. (2017), "School leadership preparation in Malaysia: aims, content and impact”, Educational Management Administration and Leadership, Vol. 45 No. 6, pp. 1002-1019, doi: 10.1177/ 1741143216662922.

Ngok, K.L. (2007), "Chinese education policy in the context of decentralization and marketization: evolution and implications education policy prior to the economic reform education policy since the economic reform: an overview", Asia Pacific Education Review, Vol. 8 No. 1, pp. 142-157, available at: https://files.eric.ed.gov/fulltext/EJ768972.pdf

OECD (2006), OECD (2006) PISA 2006 Science Competencies for Tomorrow's World, Vol. 1, Analysis, Organisation for Economic Co-operation and Development, Washington, DC and Paris.

OECD (2015), Scaling Procedures and Construct Validation of Context Questionnaire Data, PISA 2015 Technical Report, Organisation for Economic Co-operation and Development, Washington, DC and Paris, pp. 289-344, doi: 10.1787/9789264167872-17-en.

OECD (2016), "International data products", PISA 2015 Results, Vol. 1, Excellence and Equity in Education, Organisation for Economic Co-operation and Development, Washington, DC and Paris, pp. 375-382, doi: 10.1787/9789264266490-en.

OECD (2019), Balancing School Choice and Equity: An International Perspective Based on Pisa, Organisation for Economic Co-operation and Development (PISA), Washington, DC and Paris, doi: $10.1787 / 2592$ c974-en.

Sahlberg, P. (2006), "Education reform for raising economic competitiveness", Journal of Educational Change, Vol. 7 No. 4, pp. 259-287, doi: 10.1007/s10833-005-4884-6.

Sahlberg, P. (2016), "The global educational reform movement and its impact on schooling”, in Mundy, K., Green, A., Lingard, B. and Verger, A. (Eds), The Handbook of Global Education Policy, WileyBlackwell, London, pp. 128-144.

Schleicher, A. (2009), "Securing quality and equity in education: lessons from PISA", PROSPECTS, Vol. 39 No. 3, pp. 251-263.

Sellar, S. and Lingard, B. (2013), "Looking east: Shanghai, PISA 2009 and the reconstitution of reference societies in the global education policy field", Comparative Education, Vol. 49 No. 4, pp. 464-485, doi: 10.1080/03050068.2013.770943.

Shahjahan, R.A. (2016), "International Organizations (IOs), epistemic tools of influence, and the colonial geopolitics of knowledge production in higher education policy", Journal of Education Policy, Vol. 31 No. 6, pp. 694-710.

Tan, C. (2012), "The culture of education policy making: curriculum reform in Shanghai", Critical Studies in Education, Vol. 53 No. 2, pp. 153-167, doi: 10.1080/17508487.2012.672333. 
Tan, C. (2017), "Chinese responses to Shanghai's performance in PISA”, Comparative Education, Vol. 53 No. 2, pp. 209-223, doi: 10.1080/03050068.2017.1299845.

Tasaki, N. (2017), "The impact of OECD-PISA results on Japanese educational policy", European Journal of Education, Vol. 52 No. 2, pp. 145-153, doi: 10.1111/ejed.12217.

The World Bank (2011), "Malaysia economic monitor", Brain drain, p. 610. doi: 10.1017/ CBO9781107415324.004.

Thien, L.M. (2016), "Malaysian students' performance in mathematics literacy in PISA from gender and socioeconomic status perspectives", The Asia-Pacific Education Researcher, Vol. 25 No. 4, pp. 657-666.

Thompson, G.L. and Allen, T.G. (2012), "Four effects of the high-stakes testing movement on African American K-12 students", Journal of Negro Education, Vol. 81 No. 3, pp. 218-227.

Vernez, G., Karam, R. and Marshall, J.H. (2012), Implementation of School Based Management in Indonesia, Santa Monica, CA.

Walker, A. and Hallinger, P. (2015), "A synthesis of reviews of research on principal leadership in East Asia”, Journal of Educational Administration, Vol. 53 No. 4, pp. 554-570, doi: 10.1108/MIP-052017-0088.

Williams, J.H. and Engel, L.C. (2013), “Appendix to the special issue”, Research in Comparative and International Education, Vol. 8 No. 3, pp. 409-414, doi: 10.2304/rcie.2013.8.3.409.

You, Y. and Morris, P. (2016), "Imagining school autonomy in high-performing education systems: East Asia as a source of policy referencing in England", Compare: A Journal of Comparative and International Education, Vol. 46 No. 6, pp. 882-905, doi: 10.1080/03057925.2015.1080115.

\section{Further reading}

Schleicher, A. (2014), "Response to Dr Heinz-Dieter Meyer and others", The Guardian, 8 May, available at: www.theguardian.com/education/2014/may/08/pisa-programme-short-term-fixes

Stobart, G. (2005), "Fairness in multicultural assessment systems", Assessment in Education: Principles, Policy and Practice, Vol. 12 No. 3, pp. 275-287, doi: 10.1080/09695940500337249.

\section{Corresponding author}

CM Hugues D. Gill can be contacted at: hew.gill@hotmail.com

For instructions on how to order reprints of this article, please visit our website: 